PR-18

\title{
STRUCTURAL, MORPHOLOGICAL AND 1/f NOISE PROPERTIES OF ITO/TiO THIN FILMS BY e-BEAM EVAPORATION SYSTEM FOR OPTOELECTRONIC DEVICE APPLICATIONS
}

\author{
V. Manjunath, ${ }^{1 *}$ D. V. Sowmya, ${ }^{2}$ K. Murali Mohan Achari, ${ }^{2}$ P. Sandhya,${ }^{2}$ G. Sravya, ${ }^{4}$ \\ P. Ananda, ${ }^{3}$ and M. Krishnaiah ${ }^{1}$ \\ ${ }^{1}$ Department of Physics, Sri Padmavati Mahila Visvavidyalayam \\ (Women's University), Tirupati, A.P, India-517502. \\ ${ }^{2}$ Department of Chemistry, Sri Padmavati Mahila Visvavidyalayam \\ (Women's University),Tirupati, A.P, India-517502. \\ ${ }^{3}$ Chemical Engineering Institute, Ural Federal University, Yekaterinburg 620002, Russia. \\ ${ }^{4}$ Department of Physics, Madanapalle Institute of Technology and Science, \\ A.P. India-517325 \\ Corresponding author, E-mail: drvmanju18@gmail.com.
}

\begin{abstract}
The present research study, ITO/ $/ \mathrm{TiO}_{2}$ thin films are prepared on glass substrate by using e-beam evaporation system at different annealing temperatures $\left(300,350,400\right.$ and $\left.450{ }^{\circ} \mathrm{C}\right)$. The amorphous and crystalline natures of $\mathrm{ITO} \mathrm{TiO}_{2}$ structure was analysed by X-ray diffraction study. As the grain size becomes larger, indirectly it will develop the crystalline quality of the $\mathrm{TiO}_{2}$ films studied from AFM. The surface of $\mathrm{TiO}_{2}$ films and the crystallite size of the sample are increased gradually with respect to temperature which is observed in SEM. The elemental composition determined by the energy dispersive analysis of EDAX showed that $\mathrm{TiO}_{2}$ thin films were highly stoichiometric. The grain size and average slope of 1/f noise were increased with an increasing annealing temperature. Further, the higher optical transmittance $(\sim 93 \%)$ was obtained with $450{ }^{\circ} \mathrm{C}$ annealed ITO/ $\mathrm{TiO}_{2}$ film. The optical band gap was increases corresponding annealing temperatures $\left(300,350,400\right.$ and $\left.450{ }^{\circ} \mathrm{C}\right)$. All the above results of this present work can be utilized for solar cell and optoelectronic device applications.
\end{abstract}

